\title{
特集 強相関電子系物質における高圧力で誘起される新奇な超伝導
}

\section{水銀系銅酸化物高温超伝導体の圧力，ドーピング特性 〜より高い $T_{\mathrm{c}}$ をもつ物質は得られるか?}

Characteristics of Cuprate Superconductors Against Pressure and Carrier Doping $\sim$ How Can We Find a New Superconductor with the Highest $T_{\mathrm{c}}$ ? $\sim$

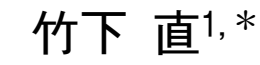

Nao TAKESHITA ${ }^{1, *}$

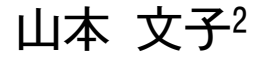

Ayako YAMAMOTO²

\section{佐々木 岬3}

Misaki SASAKI ${ }^{3}$

\begin{abstract}
We have been investigating superconducting phase diagram in various cuprate superconductors with carrier doping levels and layer numbers of $\mathrm{CuO}_{2}$ plane to figure out the condition which will realize higher superconducting transition temperature. In this article, we show the result of this study partly, and discuss the way to have a new cuprate with higher transition temperature.
\end{abstract}

[cuprate superconductor, high-pressure synthesis, superconductivity $]$

\section{1. はじめに}

銅酸化物高温超伝導体が発見されたのは 1986 年 で, 筆者の一人（竹下）は大学に入りたての学生で あった。会員諸氏にはまだ生まれていない方もいら っしゃるかもしれない。私はまだ研究室に入る前の 学生であったために, 発見直後の熱い雾囲気は味わ えなかったが，それでもテレビのニュースで連日関 連した報道があったり, 今から考えても空前絶後の 出来事であったことのように思われる。当初の $\left(\mathrm{La}_{1-\mathrm{x}} \mathrm{Ba}_{\mathrm{x}}\right)_{2} \mathrm{CuO}_{4}$ から $\mathrm{Y}$ 系が発見され超伝導転移 温度 $\left(T_{\mathrm{c}}\right)$ が液体窒素温度を越えた後も, これに続く 新規銅酸化物の発見で $T_{\mathrm{c}}$ は向上していった。現在 までの最終的な到達点は, Schilling ら[1]によって 見つけられた $\mathrm{HgBa}_{2} \mathrm{Ca}_{\mathrm{n}-1} \mathrm{Cu}_{\mathrm{n}} \mathrm{O}_{2 \mathrm{n}+2+\delta}$ に抢ける $\mathrm{n}=$ $3(\mathrm{Hg}-1223)$ であり, その転移温度は $T_{\mathrm{c}}=134 \mathrm{~K}$ と
される。結晶構造を Fig. 1a に示す。 $\mathrm{CuO}_{2}$ 面を隔 てる位置に $\mathrm{Hg}$ 原子があるため銅酸化物高温超伝導 体の中で水銀系と呼ばれるグループを形成する。 $134 \mathrm{~K}$ という温度は，銅酸化物以外の超伝導体のそ れからを考えると桁違いに高い。今後, 日常生活で 超伝導体が利用されることがあるとすれば， $T_{\mathrm{c}}$ だ けが条件ではないにせよ，より高い $T_{\mathrm{c}}$ が望まれる ので，いかに高い $T_{\mathrm{c}}$ が実現できるかを研究の中心 課題に据えることは当然である。乱暴なことを言え ば，メカニズムは不明でも経験的な方法等を駆使し て $T_{\mathrm{c}}$ を上げることができれば，それ自体が十分に 面白く意義のある研究であろう。そしてメカニズム はそこから逆に解明できるのではないかとも期待で きる。しかしながら，Hg-1223 が発見されたのは四 半世紀以上前のことであり，これよりも高い温度で 超伝導になる物質が現在まで常圧下で見出されてい

\footnotetext{
1 ₹305-8568 茨城県つくば市梅園 1-1-1＼cjkstart産総研つくば中央第 2 事業所 電子光技術研究部門

Electronics and Photonics Research Institute, National Institute of Science and Technology, 1-1-1 Umezono, Tsukuba 305-8568

2 T135-8548 東京都江東区豊洲 3-7-5 芝浦工業大学 大学院理工学研究科 Graduate School of Engineering and Science, Shibaura Institute of Technology, 3-7-5 Toyosu, Koto-ku, Tokyo 135-8548

3 × $292-0041$ 千葉県木更津市清見台東 2-11-1 木更津工業高等専門学校 電子制御工学科 Department of Electronic Control Engineering, National Institute of Technology, Kisarazu College, 2-11-1 Kiyomidaihigashi, Kisarazu, Chiba 292-0041

* Electric address: takeshita.n@aist.go.jp
} 
(a)

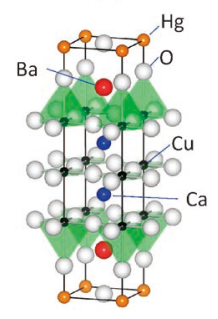

$\mathrm{HgBa}_{2} \mathrm{Ca}_{2} \mathrm{Cu}_{3} \mathrm{O}_{8+\delta}$ (b)

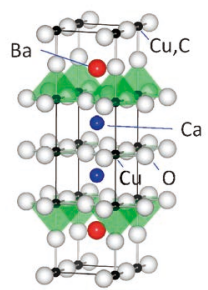

$(\mathrm{Cu}, \mathrm{C}) \mathrm{Ba}_{2} \mathrm{Ca}_{2} \mathrm{Cu}_{3} \mathrm{O}_{8+\delta}$ (c)

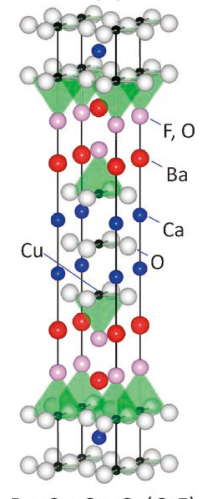

$\mathrm{Ba}_{2} \mathrm{Ca}_{2} \mathrm{Cu}_{3} \mathrm{O}_{6}(\mathrm{O}, \mathrm{F})_{2}$

Fig. 1. Crystal structure of (a) $\mathrm{Hg}-1223$, (b) $\mathrm{Cu}-1223$ [12], (c) F-0223.

ないことは，残念である。これまでの研究で多くの 銅酸化物では圧力をかけると $T_{\mathrm{c}}$ は上がることが知 られている。銅酸化物に限定する必要は全くないが， 銅酸化物のもつ可能性をもう少し努力して調べてみ ることは必要ではないか，という考えから銅酸化物 高温超伝導体に対して詳細に圧力下で実験しようと 考えた。

銅酸化物高温超伝導体に共通の結晶構造の特徵は $\mathrm{CuO}_{2}$ 面を保有することである。 $\mathrm{CuO}_{2}$ 面は全体と してマイナス 2 価の状態である。 $\mathrm{CuO}_{2}$ 面はユニッ トセル中に一層存在する場合だけではなく何層もス タックする構造をとることができ，そのバリエーシ ヨンの存在が大きな特徵の一つである。ストイキオ メトリックな母物質では $\mathrm{CuO}_{2}$ 面にはキャリアがな く, 電気伝導的には半導体的もしくは絶縁体的と呼 ぶべき状態である。ただしこの状態は $\mathrm{Si}$ のような 半導体での単純なバンド半導体ではなく, モット絶 縁体と呼ばれる状態であるが，ここでは詳しくは触 れない。Cuイオンのスピンによる反強磁性への転 移が室温付近以上の温度に存在する。ここで, 通常 は酸素量の増減等によりキャリアを導入すると, 反 強磁性転移が抑制され, $\mathrm{CuO}_{2}$ 面で電気伝導性が得 られるようになる。さらにキャリアを導入するとつ いに反強磁性が失われ，金属の基底状態が得られる ようになる。金属状態に抢いて超伝導状態が出現す るが, 超伝導相はキャリア濃度に対してドーム型の 形状をもつ(Fig. 2)。つをり, 最適ドープ量という ものが存在している。

銅酸化物高温超伝導体には様々なバリエーション

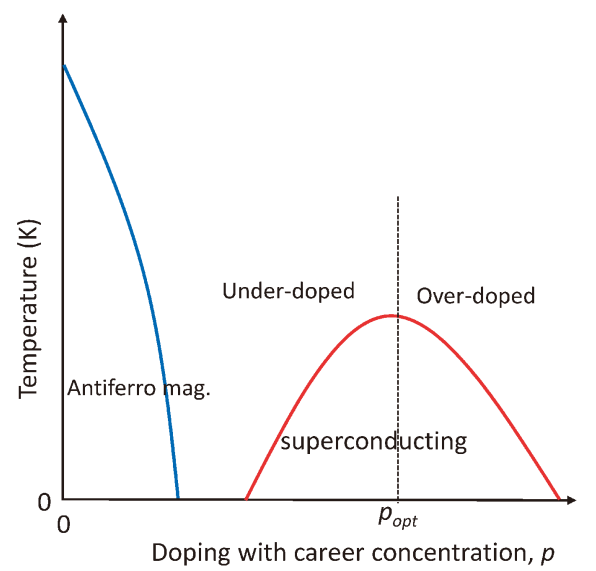

Fig. 2. The typical phase diagram of high- $T_{\mathrm{c}}$ cuprates, temperature versus career concentration.

があるが，基本的にはこの $\mathrm{CuO}_{2}$ 面がユニットセル 中に何枚含まれるか，ということと， $\mathrm{CuO}_{2}$ 面のス タック部を隔てる部分（ブロック層とよばれる）に なにが積層しているか, という違いであると理解で きる。そのため，様々な銅酸化物超伝導体を比較す ることで, $\mathrm{CuO}_{2}$ 面で起きている超伝導現象が構造 的にはどのような要因が超伝導転移温度に関与して いるのか，ということに対する大きなヒントを得ら れると期待できる。しかし，ドーピングによるキャ リアの量など様々の要因も絡み合っているので, 考

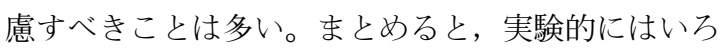
いろのブロック層をもつ銅酸化物に対して，1. 工 ニットセル中の $\mathrm{CuO}_{2}$ 面の数 $(\mathrm{n})$ による違い, 2 . ドーピング量による違い, に応じて圧力下で超伝導 圧力相図をそれぞれ構築して, 比較, 検証してみる 必要がある。地道な研究であるが, 従来の多くの超 伝導体では $T_{\mathrm{c}}$ は加圧によって低下することが多い のに対して，銅酸化物は上昇することが多い $[2]$ 。 加圧によってバンド幅が広がり状態密度が下がると いうのが $T_{\mathrm{c}}$ が下がることの単純な解釈である。で は銅酸化物では何が起きているのであろう。我々は 様々な銅酸化物の圧力下実験を進めているが，本稿 ではその結果の一部を示したい。

Hg-1223 が最も高い $T_{\mathrm{c}}$ をもつことが報告された 直後に圧力下での $T_{\mathrm{c}}$ の振る舞いに興味がもたれた。 最も高い $T_{\mathrm{c}}$ をもつ物質を圧力下でさらに高めれば, すなわち世界で最も高い超伝導転移温度となるので, これは当然である。最初に, Chu らが $15 \mathrm{GPa}$ まで の実験 [3]を行った。この際の圧力領域は低圧側と 
高圧側の二つに分けて実験が行われた。低圧側では ピストンシリンダー型装置が, 高圧側では固体圧力 媒体を用いたブリッジマン型の対向アンビル型装置 での実験が行われた。Fig. 3 に示すように, 低圧側 では超伝導転移に伴うゼロ抵抗が得られているが， 高圧側ではゼロ抵抗が得られていない。先ほど述べ たように, 超伝導の舞台になっているのは $\mathrm{CuO}_{2}$ 面 なので, 加圧によって $\mathrm{CuO}_{2}$ 面が乱れてしまう等, 静水圧性の低い実験では超伝導現象そのものに大き な影響があることは想像できる。しかし，この報告 では電気抵抗の落ち始めで圧力下の $T_{\mathrm{c}}$ を認定して しまい圧力下の正しい超伝導相図が得られていない と考える。最適ドープの Hg-1223 は常に上凸の電 気抵抗率の温度変化を示すので, 落ち始めという定 義そのものが難しい。同じ $T_{\mathrm{c}}$ の決定方法を用いて， さらに高い圧力下までの実験がその後 Gao らによ り行われた $[4]$ 。本研究による結果や, その後の $\mathrm{H}_{2} \mathrm{~S}$ による更なる記録更新 $[5]$ までの 20 年以上の間, この Hg-1223の $31 \mathrm{GPa}$ で $163 \mathrm{~K}$ という最高記録が 独り歩きすることになった。生データは典型的な非 静水圧性によって生じた「乱れ」が超伝導現象その ものに影響を及ぼしたものに見える。学理として正 確な超伝導圧力相図をつくり, そこから有用な解釈 なりを導き出して, 新たな物質設計につなげること が重要で, 再度, 系統的に取り組む価值が十分ある と思えた。そこで，まず我々は Hg-1223 に圧力を 加えることで $T_{\mathrm{c}}$ がどのように変化するのかを結論 づけよう考えた。

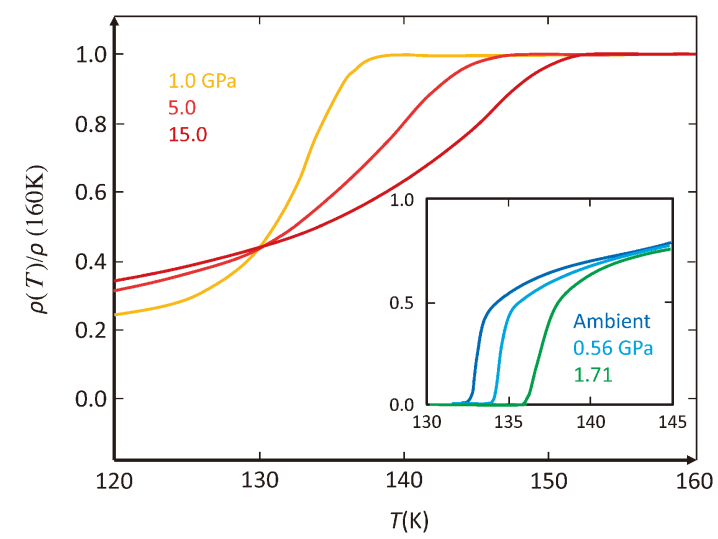

Fig. 3. Trace of normalized resistivity at high pressure of $\mathrm{Hg}-1223$ by Chu et al. [3].

\section{2. 実験}

先ほど述べたように，この実験では「乱れ」を排 除しなくては実験はうまくいかない。良い圧力，良 い試料の双方が必要である。良い圧力というのは, 静水圧性と到達圧力の高さの両者が確保されること を意味する。常圧下で測定と同じクオリティでの測 定を行い, 同じ $T_{\mathrm{c}}$ の決定方法を用いて評価して正 確な圧力下の超伝導相図を作りたい。10 GPa クラ スの圧力領域で最も優れていると思われる装置はキ ュービックアンビル型の高圧装置 $[6]$ であろう。キ ュービックアンビル装置は基本的に大型であるので, 極低温への冷却は難しいが，今回の実験対象は幸い 測定温度領域が高い。キュービックアンビル装置の 最も優れた点は静水圧性の確保を圧力媒体の久に頼 らず等方的な圧縮機構によって実現しているという ところである。圧力媒体は加圧や冷却によっていず れ固化するが，等方的な圧縮を行うことで圧力媒体 の固化前後で大きな状況の変化が生じない。従って, 最も低い圧力から高い圧力まで同じ状況で結果を比 較することができる。

試料作製も同様に重要である。まず，良い試料を 準備するということだが，この際の「良い」試料と いう意味は単純にその $T_{\mathrm{c}}$ が高い，というだけでは ない。まず，単結晶か多結晶か，ということがある。 単結晶のほうが良い結晶, という考えかたが一般的 かもしれないが，まず $\mathrm{Hg}$ 系銅酸化物では単結晶を 得るのが困難であるということがある。また，今回 の実験で求めたいのは，等方的な圧力による効果な ので, 試料が純良であれば多結晶試料は試料そのも のが圧力媒体として働き, 圧力効果を試料自体でも 平均化して示してくれることが期待できる。さらに もう一つ重要なこととして, 圧力実験に用いる試料 は，できるだけ稠密であることが求められる。たと えば，Chu らの実験 [3]に打ける低圧側の結果を見 ると, ピストンシリンダーによる実験であるのでゼ 口抵抗が得られているが，加圧によってだんだん転 移がブロードになっている様子がみられる。これは 試料が稠密でないために, 加圧によって内部の巣の 部分などが押しつぶされて結晶自体に乱れが導入さ れるためである。 $\mathrm{Hg}$ 系高温超伝導体のバルク試料 を合成するには，石英封管法と高圧法の 2 種がある。 どちらでも条件さえ整えば良質な試料を得ることは 可能であるが，我々は試料を高圧法により合成した。 上記方法の合成上の最も重要な違いは, セル内に試 
料以外の残余体積があるか否かである。 $\mathrm{Hg}$ 系の試 料生成プロセスは, $\mathrm{Hg}$ 気体とその他の金属酸化物 が反応する気一固反応であるため, 石英封管法では, $\mathrm{Hg}$ 分圧と組成比の制御が困難である。このように, 高圧法が今回の実験では最適な合成方法であること が分かる。これについて，さらに詳細を述べる。

高圧合成法に抢いては，(1)すべての金属酸化物 $\left(\mathrm{HgO}, \mathrm{BaO}_{2}, \mathrm{CaO}, \mathrm{CuO} / \mathrm{Cu}\right)$ を一度に反応させる直 接法と, (2) $\mathrm{HgO}$ と $(\mathrm{Ba}-\mathrm{Ca}-\mathrm{Cu}-\mathrm{O})$ を反応させる前 駆体法がある。この両方を実施し, その違いを検討 した。いずれの場合でも，如何に炭酸塩を含んだ不 純物を原料段階で取り込まないかが重要である。前 駆体の合成には真空加熱後に高純度酸素 (99.999\%) でアニールし, 原料, 前駆体の混合はすべてグロー ブボックス内で行うなど炭酸不純物には細心の注意 を払った。シリンダー状に成型した試料は金セルに 充填し, 絶縁体, ヒーター, 圧媒体を介して, 比較 的小型のキュービックアンビル型高温高圧プレス (TRY180)で $2 \mathrm{GPa}, 800-920^{\circ} \mathrm{C}$ の熱処理を行った。 試料は XRD, SEM で評価し, SQUID を用いた磁 化測定と 4 端子法を用いた電気抵抗測定を行い評価 した。

Hg-1223を目的とした組成比から出発した場合, 直接法と前駆体法では最適焼成温度が異なった。直
接法では $890^{\circ} \mathrm{C}$ の時はほぼ $\mathrm{Hg}-1223$ のみであった が, $860^{\circ} \mathrm{C}$ では $\mathrm{CuO}_{2}$ 面の数の違うバリエーション の $\mathrm{Hg}-1212,920^{\circ} \mathrm{C}$ では Hg-1234 が共存した。一方, 前駆体法では $830^{\circ} \mathrm{C}$ が最適で $\mathrm{Hg}-1223$ のみが得ら れたが， $800^{\circ} \mathrm{C}$ では $\mathrm{Hg}-1212,860^{\circ} \mathrm{C}$ では $\mathrm{Hg}-1234$ が共存した。このように最適な温度ウインドウが狭 いので, $6 \mathrm{~mm}$ ほどの円柱試料の中心が Hg-1223 の みでも, 端では Hg-1212 が共存した。また, 原料 の粒径サイズやそのばらつきによっても共存相が異 なった。例えば, $\mathrm{CuO}$ が 0.5-5 $\mu \mathrm{m}$ とばらついてい るときは，Hg-1223，Hg-1212，Hg-1234の 3 相が一 気に現れるが， $1 \mu \mathrm{m}$ でそろっている時は Hg-1223 のみが得られた。このように高圧合成でも単相を得 るのは容易ではないが，一度条件を決めれば，再現 性が良く, また, 何より緻密で加工性の良い焼結体 が得られる。そのほかにも，前駆体に酸素を余分に 取り込ませることで, 事後アニールでは得られない 程のオーバードープの試料が得られるなどの利点が ある。

\section{3. 結果}

まず最初に行った $\mathrm{Hg}-1223$ の $T_{\mathrm{c}}=130 \mathrm{~K}$ の試料 に対する圧力印加に伴う電気抵抗率の温度依存性の

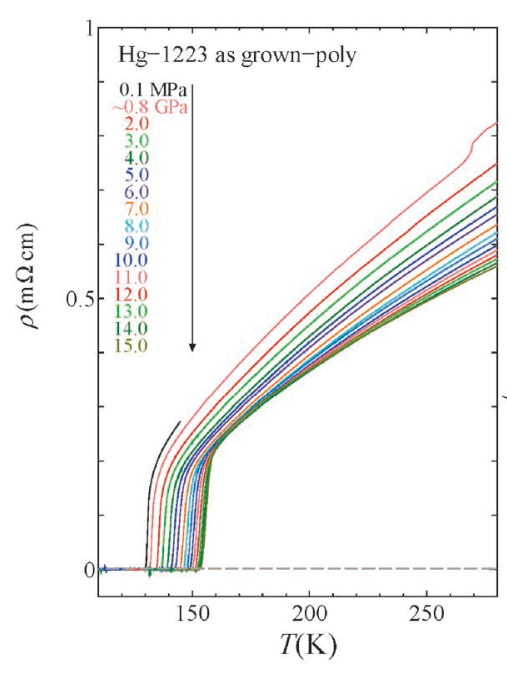

(a)

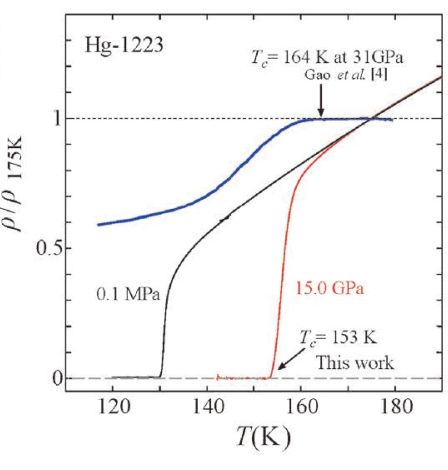

(b)

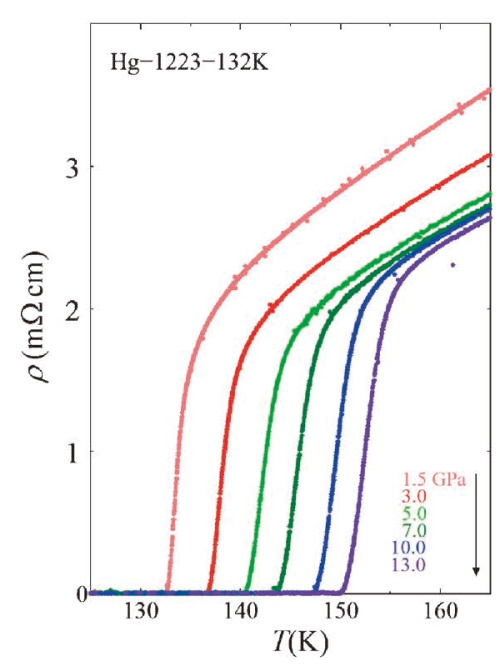

(c)

Fig. 4. (a) Resistivity results of $\mathrm{Hg}-1223\left(T_{\mathrm{c}}=130 \mathrm{~K}\right)$ at high pressure, (b) normalized resistivity of $\mathrm{Hg}-1223$, trace of former study by Gao[4] (blue), and our results at ambient pressure and at $P=15.0 \mathrm{GPa}$, (c) resistivity results of $\mathrm{Hg}-1223$ $\left(T_{\mathrm{c}}=132 \mathrm{~K}\right)$ at high pressure. 
変化を述べる。前述のように, この試料は非常に均 質かつ稠密な試料である。ただし若干超伝導転移温 度が低く，これはわずかにアンダードープな試料で あると考えられた。結果を Fig. $4 \mathrm{a}$ に示す。 $T_{\mathrm{c}}$ は加 圧とともに上昇し, 最高圧力となった $15 \mathrm{GPa}$ にお いてもさらに上がり続けている。超伝導転移に伴う ゼ口抵抗状態はすべての圧力下で得られた。常圧下 と同様にゼ口抵抗温度によって超伝導転移温度を定 義し, 圧力下超伝導相図をつくると Fig. 5 に示す 結果となった。最高圧力に打いて, $T_{\mathrm{c}}=153 \mathrm{~K}$ が得 られた $[7,8]$ 。この結果は現在も銅酸化物高温超伝 導体に扔いては最も高い温度でのバルク超伝導現象 である。Chuらによるこれまでの結果は加圧に従

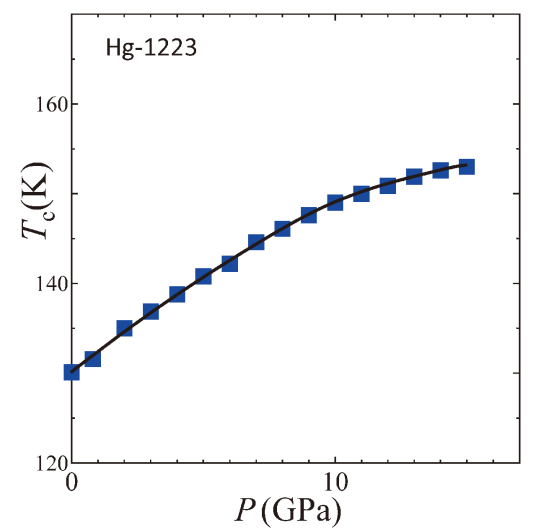

Fig. 5. Pressure phase diagram of $T_{\mathrm{c}}$ in slightly under doped $\mathrm{Hg}-1223\left(T_{\mathrm{c}}=130 \mathrm{~K}\right)$.

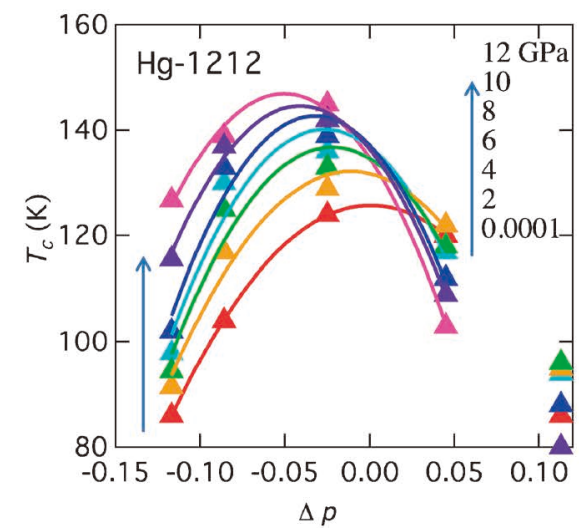

つて試料の破壊が進及電気抵抗率の絶対值に大幅な 上昇があったと推察され，結果を見やすくするため に $175 \mathrm{~K}$ に抢ける電気抵抗率で規格化して示されて いる。これに倣って今回の結果を以前の結果を比べ てみたものが Fig. 4b である。仮に電気抵抗率の落 ち始めという定義を考慮してもよいのだとすると， 我々の結果でも常圧との不一致の起きる $T_{\mathrm{c}}$ は $170 \mathrm{~K}$ 近くまで上昇しているようにも解釈できる。 よりMao らの決定法に忠実に微分の異常による転 移の定義を採用しても $160 \mathrm{~K}$ 近くの值になってしま う。これらはゼ口抵抗温度の $153 \mathrm{~K}$ との差が著しく 大きい。超伝導現象は相転移現象であるので, 当然 超伝導状態であれば抵抗が 0 になる, ということで 決定するのが望ましい。ここから逆にこれまでの結 果は overestimation であると考えるのが自然である。 正確な結果を得るには, 十分にシャープな超伝導転 移をもつ試料で, 圧力下に掞いてもゼロ抵抗で転移 温度を評価しなければ超伝導体の圧力下相図として は正確性に欠けることは明らかである。

はじめの実験では $T_{\mathrm{c}}=130 \mathrm{~K}$ の試料で実験を行っ たが，これは最適ドープよりも少し低い転移温度の 試料である。従って, 最適ドープの試料を用いれば さらに高い $T_{\mathrm{c}}$ を期待できるのではないかと考えて 今度は $T_{\mathrm{c}}=132 \mathrm{~K}$ の同等なクオリティの試料を用意 して行った。結果を Fig. 4c に示す。途中をでは確 かにこの試料のほうが高い転移温度を示していたが， 最終的に高圧力下では $T_{\mathrm{c}}$ の上昇が止まり逆転する, という結果になった。期待した結果ではなかったが, これは精査する必要があると考えられたので,

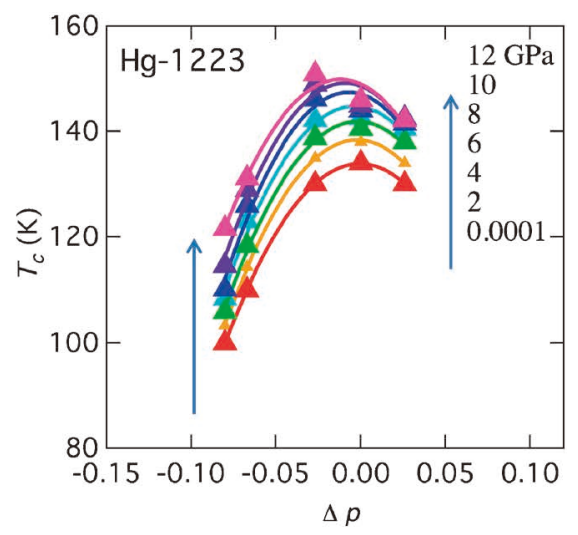

Fig. 6. $T_{\mathrm{c}}$ versus $\Delta_{\mathrm{p}}$ of $\mathrm{Hg}-1212$ (left) and $\mathrm{Hg}-1223$ (right) at high pressures after ref. [8]. The value of $\Delta_{\mathrm{p}}$ was determined by $p-p_{\text {opt }}$, where $p$ is the career concentration of each samples and $p_{\text {opt }}$ is $p$ with maximum $T_{\mathrm{c}}$ under ambient pressure, i.e. $\Delta_{\mathrm{p}}<0, \Delta_{\mathrm{p}}=0$, and $\Delta_{\mathrm{p}}>0$ shows the under, the optimum, and the over doping state, respectively. 
$\mathrm{Hg}-1223$ およびさらにシンプルな $\mathrm{CuO}_{2}$ 層がユニッ トセルあたり 2 枚である Hg-1212の双方に対して， アンダードープ, 最適ドープ, オーバードープの試 料を用意してそれぞれ加圧を行った結果 $[8]$ が Fig. 6 である。

このように，現象論的には 2 枚もの， 3 枚もの共 に, ややアンダードーピングで低い転移温度をもつ 試料が圧力下では最も高い $T_{\mathrm{c}}$ に到達した。また, $\mathrm{Hg}-1212$ では $20 \mathrm{GPa}$ 付近までの結果 $[8]$ を見ると， さらに加圧すると転移温度は減少に転ずることが分 かってきた。Hg-1223の場合は, 圧力下の最高 $T_{\mathrm{c}}$ は $153 \mathrm{~K} よ り$ 少し上, 圧力は $20 \mathrm{GPa}$ あたりで実現 されると考えられる。これはまだ実験的に確認はし ていないが， $20 \mathrm{GPa}$ 近くでは圧力に対して上昇が ほぼ飽和してしまう様子は確認されている $[8]$ 。こ の結果について, 圧力によって最適ドープとなるキ ヤリア濃度が変化するのか, あるいはキャリア濃度 そのものが圧力で変化するのか, という解釈ができ そうだが，これについてもまだ検討できていない。

\section{4. さらに高い $\boldsymbol{T}_{\mathrm{c}}$ をもつ物質は得られるか？}

銅酸化物高温超伝導体の結晶構造はすでに示した が，これを見ても容易に想像できるように，等方的 な圧力を加えても, 各軸の圧縮率は当然異なり, そ して各軸ごとの圧力効果は異なるであろう。たとえ ばLa系に抢ける Nakamura らの先行研究[9]にお いてもその効果が示されている。また最近では美藤 らによるDAC 中に㧍いて, 静水圧と異方的圧力効 果とを分離して考察する水銀系試料に対する研究が ある $[10]$ 。我々も，これを明らかにできないかと考 え $\mathrm{Hg}$ 系の類型物質として頂点フッ素型抢よび $\mathrm{Cu}$, C 系の銅酸化物について同様の実験を行った。これ ら二つの銅酸化物の結晶構造は Fig. 1 に示す通り で $\mathrm{Hg}$ 系とよく似ている。大きな違いはユニットセ ル間のつなぎ目のブロック層の部分にある。最外層 の $\mathrm{CuO}_{2}$ 面の $\mathrm{Cu}$ の直上にある酸素は頂点酸素々呼 ばれ，その役割が重要視されることが多い。水銀系 ではこの頂点酸素の位置が他と比べて遠く,これが 水銀系の高い $T_{\mathrm{c}}$ に対して重要な役割を果たしてい るとされる。頂点フッ素ではこの位置に酸素がなく フッ素が置かれている。Cu, C 系では頂点酸素があ り, 頂点酸素間に $\mathrm{Cu}$ あるいは $\mathrm{C}$ 原子が配置され, さらに水銀系に近い形になっているが，頂点酸素と の距離が近い。

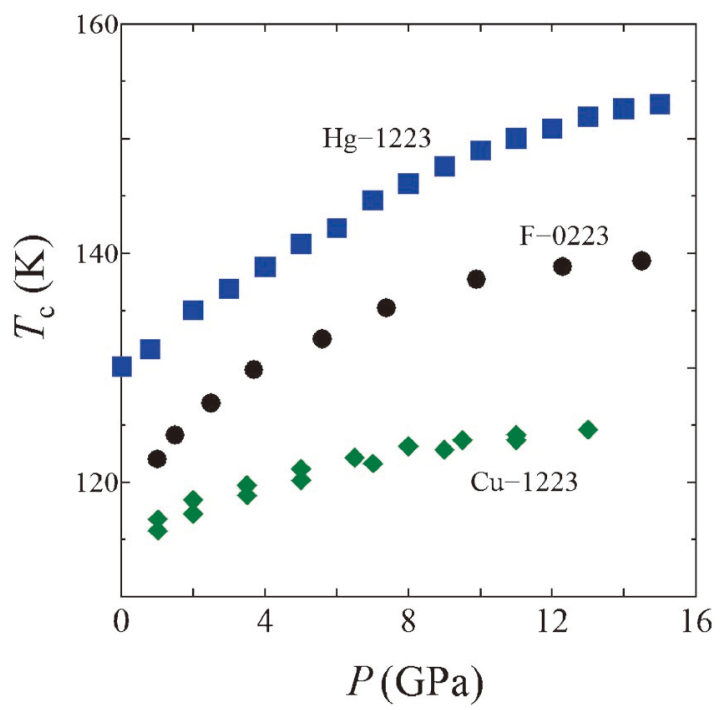

Fig. 7. Pressure phase diagram of nearly optimally doped cuprates with three $\mathrm{CuO}_{2}$ planes in unit cell. Enhancement in $\mathrm{Cu}-1223$ is clearly short.

試料は同様にすべて高圧合成法で作成した。これ らの $\mathrm{CuO}_{2}$ 面が 3 枚の試料 ( $\mathrm{Hg}-1223, \mathrm{Cu}-1223$, F-0223)に扔いて最適ドープ付近の試料に関する測 定を行い， $T_{\mathrm{c}}$ を決定して相図を作成すると Fig. 7 のようになる。

常圧に打ける転移温度はそれぞれ違うので, 加圧 に伴う $T_{\mathrm{c}}$ の上昇分に注目すると, 頂点フッ素系で は $\mathrm{Hg}$ 系とほぼ同等の上昇傾向がみられるが $\mathrm{Cu}, \mathrm{C}$ 系では上昇が半分程度になった。水銀系, 頂点フッ 素系， $\mathrm{Cu}, \mathrm{C}$ 系それぞれの格子定数 $\mathrm{a}$, つまり $\mathrm{CuO}_{2}$ 面にはそれほど大きな差はない。違いは $\mathrm{c}$ 軸 方向の構造や圧縮にあると考えられる。この結果に ついて我々は， $1 . T_{\mathrm{c}}$ 上昇の一番大きな要因は $\mathrm{a}, \mathrm{b}$ 軸の圧縮による $\mathrm{CuO}_{2}$ 面の圧縮によるもの, 2. 頂 点酸素との距離やここからもたらされる乱れによる 影響が $T_{\mathrm{c}}$ を押し下げる，と考えている。この 1 . と 2.の相反する効果のせめぎあいによって圧力下の $T_{\mathrm{c}}$ がどう変わるか決をる。 $\mathrm{Hg}$ 系と頂点フッ素系に 拈ける $T_{\mathrm{c}}$ の上昇分がほぼ同程度であるということ は, 頂点フッ素と $\mathrm{Hg}$ 系に特徵的な頂点酸素の高さ 等の状況が $\mathrm{c}$ 軸方向の圧縮をうけてもどちらも同程 度に变化し, 悪影響もほぼ同程度に増えていくこと を意味していると考えている。常圧に抢ける $T_{\mathrm{c}}$ の 差は頂点フッ素型ではフッ素が全ての位置に入って いるわけではなく，これによって $\mathrm{CuO}_{2}$ 面に乱れが 
加わり，その分 $T_{\mathrm{c}}$ が低いのではないかと考えられ る。これに対して $\mathrm{Cu}, \mathrm{C}$ 系ではもともとの頂点酸 素の位置が低く, これにより常圧の $T_{\mathrm{c}}$ も低く, $\mathrm{CuO}_{2}$ 面の圧縮による利得はあるが, 加圧時の頂点 酸素位置が下がってくる効果による悪影響も大きい ため, 結果として $\mathrm{Hg}$ 系の半分程度の $T_{\mathrm{c}}$ 上昇しか 得られなかったのではないかと考えられる。

本研究においては正確な圧力相図を作ることが第 一の目的ではあるが，その先にあるものは銅酸化物 高温超伝導体でより高い $T_{\mathrm{c}}$ を実現することができ るか？ということである。さらに高い転移温度を 実現するには，どのような方策が考えられるかだろ うか。実験から分かったことは，やはり $\mathrm{Hg}$ 系が一 番高い転移温度をもつということは当初から言われ ていたように頂点酸素の高さが効いているというこ とである。もう一つ, これもほぼ予想通りのことで あるが, $\mathrm{CuO}_{2}$ 面の圧縮による利得と頂点酸素の降 下による損失のせめぎあいで $T_{\mathrm{c}}$ が決定されるとい うことがはっきりしてきた。したがって，きわめて 単純な結論ではあるが, c 軸には圧縮せず（可能な ら伸長させ） $\mathrm{a}, \mathrm{b}$ 軸には压縮を行う，ことができれ ば $T_{\mathrm{c}}$ は間違いなく向上するのではないかと考えら れる。そして，新物質としてこれを常圧で実現でき れば，Hg-1223の $T_{\mathrm{c}}$ を超えるようなものになるに 違いない。Hardy ら[11]によるこのような軸ごと の圧力効果の打ち消し合いに関する考察の結果もあ る。

圧力下の実験としてこれを実現させるためには， 選択的に $\mathrm{a}, \mathrm{b}$ 軸への加圧を行うようなアプローチ を行えばいい。これに関しては先駆的な実験が Nakamura らによって行われている[9]。

ここで難しいことは，Hg-1223の単結晶が得られ るか，ということともう一つは如何に上手に均質で 異方的圧力を試料に加えることができるか，という ことである。上記の均質で異方的という意味は，た とえば圧力発生空間で上下方向の圧力と左右の平面 方向の圧力值が違い, かつ圧力発生空間のどこでも 均質にそのような圧力が発生している，という意味 である。従って，いま水平方向の圧力が高くなるよ うな圧力をうまく作り出すことができれば，そこに 単結晶をうまく設置すれば $\mathrm{CuO}_{2}$ 面が選択的に圧縮 されるような状況が作り出され，これによってより 効果的に $T_{\mathrm{c}}$ を向上させることができるのではない かと想像できる。同じような考えとして，たとえば 圧電素子に単結晶試料をうまく貼り付けて, 圧電素
子に電圧を印加することによって $\mathrm{CuO}_{2}$ 面を選択的 に圧縮することができればやはり同じように転移温 度が変わる様子を観測できるのではないかと思って いる。

次に圧力実験ではなく試料作製側のアプローチを 考えると, Hg-1223 で元から a, b 軸が短い試料が あれば，打そらく間違いなく $T_{\mathrm{c}}$ は $134 \mathrm{~K}$ を超える ものになるであろう。ここでアイデアはいろいろあ るが，たとえば Hg-1223の最外面の上にある Ba イ オンをより半径の小さい $\mathrm{Sr}$ に置き換えたような試 料, つまり $\mathrm{HgSr}_{2} \mathrm{Ca}_{2} \mathrm{Cu}_{3} \mathrm{O}_{8+\delta}$ という試料を作るこ とができればよい。このような試料作製の報告は我 々の知るところではまだないが，本当にないのか， 非常に困難ではあるが実現できるのかは今のところ 分からない。ほかにも, 少し格子定数の小さい基板 上で Hg-1223 をエピタキシャル成長させて $\mathrm{a}, \mathrm{b}$ 軸 のみを圧縮した試料を得ることを思いつく。ただ，

$\mathrm{Hg}$ の蒸気圧の制御や $\mathrm{Hg}$ の揮発性の問題などがク リアされなければならない。頂点酸素の位置さえ適 切であれば $a, b$ 軸が短い状態が実現でき最適な量 のキャリアが入れば転移温度は高くなると思われる。 あるいは $\mathrm{Hg}$ 系に限らず，ベースとなるもっと他の 候補物質もあるかもしれない。

\section{5. おわりに}

実験をいろいろの試料で行って感じたことは，銅 酸化物高温超伝導体の圧力下の実験は必要とする静 水圧環境が大変重要である, ということである。個 人的な経験で恐縮だが，学生の頃に対向アンビル装 置を用いて重い電子系超伝導試料の圧力下実験を行 ったところ，ことごとくゼロ抵抗が得られなく苦労 したことがある。加圧で試料が割れるような圧力で はそもそも実験の成功は望めないという経験だった のだが，銅酸化物も同様であると感じる。すこしの 非静水圧性によって超伝導状態そのものに大きな影 響が生じてしまう。 $T_{\mathrm{c}}$ の上昇/低下だけの評価なら ばそれでも可能かもしれないが，定量性を見るよう な実験を実現するためには $\mathrm{CuO}_{2}$ 面に加わる乱れは できるだけ小さくしなければ有用な結果とならない。 この点で, 本研究はキュービックアンビル型（大杉 型）の装置をもつ日本だけでできる興味深い分野と して, まだまだ研究の余地があると考えている。 
謝 辞

本研究は JSPS 科研費 16H04338, 23340110, 26247057 の助成を受けたものです。

\section{参考文献}

[1] A. Schilling, M. Cantoni, J.D. Guo, H.R. Ott: Nature, 363, 56 (1993).

[2] H. Takahashi, N. Mori: in Study of High Temperature Superconductors, ed. A. Narlikar (Nova Science, New York, 1996), Vol. 16, pp. 1-63. [3] C.W. Chu, L. Gao, F. Chen, Z.J. Huang, R.L. Meng, Y.Y. Xue: Nature, 365, 323 (1993).

[4] L. Gao, Y.Y. Xue, F. Chen, Q. Xiong, R.L. Meng, D. Ramirez, C.W. Chu, J.H. Eggert, H.K. Mao: Phys. Rev. B, 50, 4260 (1994).

[5] A.P. Drozdov, M.I. Eremets, I.A. Troyan, V. Ksenofontov, S.I. Shylin: Nature, 525, 73 (2015).

[6] N. Mori, H. Takahashi, N. Takeshita: High
Pressure Res., 24, 225 (2004).

[7] N. Takeshita, A. Yamamoto, A. Iyo, H. Eisaki: J. Phys. Soc. Jpn., 82, 023711 (2013).

[8] A. Yamamoto, N. Takeshita, C. Terakura, Y. Tokura: Nat. Comm., 6, 8990 (2015).

[9] F. Nakamura, J. Hori, T. Goko, Y. Uno, N. Kikugawa, T. Fujita: J. Low Temp. Phys., 117, 1145 (1999).

[10] M. Mito, K. Ogata, H. Goto, K. Tsuruta, K. Nakamura, H. Deguchi, T. Horide, K. Matsumoto, T. Tajiri, H. Hara, T. Oazaki, H. Takeya, Y. Takano: Phys. Rev. B, 95, 064503 (2017).

[11] F. Hardy, N.J. Hiller, C. Meingast, D. Colson, Y. Li, N. Barišić, G. Yu, C. Zhao, M. Greven, J.S. Shilling: Phys. Rev. Lett., 105, 167002 (2010).

[12] T. Kawashima, Y. Matsui, E. TakayamaMuromachi: Physica C: Superconductivity, 224, 69 (1994).

[2019年 9 月 29 日受付, 2019 年 11 月 6 日受理 $]$ (C) 2019 日本高圧力学会 